


\section{Habitar el cuerpo abyecto: realización escénica a partir de un laboratorio escénico ${ }^{1}$}

\section{Artículo de investigación}

Recibido: 5 de agosto de 2020

Aprobado: 9 de octubre de 2020

\section{Amanda Méndez Ramírez}

Universidad de Costa Rica, Costa Rica

amanda.mendez@ucr.ac.cr

Cómo citar este artículo: Méndez Ramírez, Amanda (2021). Habitar el cuerpo abyecto: realización escénica a partir de un laboratorio escénico. Estudios Artísticos: revista de investigación creadora, 7(10) pp. 110-128.

DOI: https://doi.org/10.14483/25009311.17516

\section{Agradecimientos}

Muchas gracias al IX Congreso Cuerpo en el Siglo XXI: Aproximaciones Heterodoxas desde América Latina, al Doctorado en Estudios Artísticos de la Universidad Distrital Francisco José de Caldas, en Bogotá y a Estudios Artísticos: Revista de investigación creadora.

$<$

Habitar el cuerpo abyecto: realización escénica a partir de un laboratorio escénico. Amanda Méndez Ramírez, (2019). Fotografía: Nathalie Méndez.

\footnotetext{
1 Investigación artística, donde presento, de manera detallada, los resultados originales de mi proyecto de investigación en Licenciatura en Artes Dramáticas de la Universidad de Costa Rica. La presente investigación artística es un estudio conceptual del cuerpo abyecto a través de una realización escénica, producto del informe de proyecto de graduación para optar por el grado de Licenciada en Artes Dramáticas de la Universidad de Costa Rica, en el año 2019.
}

\section{Resumen}

Esta investigación artística persigue la conceptualización del cuerpo abyecto, comprendido de forma teórica y escénica. Se divide en tres partes: un estudio teórico, un laboratorio escénico y un montaje/desmontaje escénico. Se sustenta teóricamente con el trabajo de Judith Butler: Cuerpos que importan, sobre los límites materiales y discursivos del sexo (2008), Julia Kristeva: Poderes del horror. Sobre la abyección (1988); la metodología se sustenta en el texto de Ericka Fischer-Lichte: Estética de lo performativo (2017). La investigación culmina con la creación de una dramaturgia corporal a partir de lo creado en el laboratorio escénico, y un breve desmontaje del proceso de creación e investigación escénica. Entre los principales hallazgos se rescata la comprensión y estudio escénico de un concepto, la posibilidad del arte escénico para generar nuevo conocimiento y las posibilidades expresivas del cuerpo en escena.

\section{Palabras clave}

Cuerpo abyecto; danza teatro; laboratorio escénico; realización escénica; performance; teatro físico.

\section{Inhabiting the Abject Body: Stage Production from a Stage Laboratory}

\footnotetext{
Abstract

This art-based research seeks the ideation of the abject body, understood in a theoretical and stage sense. It is divided into three parts: a theoretical study, a stage laboratory and a stage production/ disassembly. It is theoretically supported by the work of Judith Butler: Bodies that Matter, on the Discursive Limits of Sex (2008), Julia Kristeva:
} 
Powers of Horror. An Essay on Abjection (1988); The methodology is based on Ericka FischerLichte's text: Aesthetics of the Performative (2017). Our research culminates in the creation of a corporal dramaturgy based on what was created in the stage laboratory, and a brief disassembly of the process of creation and stage research. Among the main findings is the understanding and study on stage of a concept, the possibility of performing art to generate new knowledge and the expressive possibilities of the body on the drama stage.

\section{Keywords}

Abject body; dance theater; stage laboratory; stage production; performance; physical theater

\section{Habiter le corps abject : une production théâtrale à partir dsun laboratoire scénique}

\section{Résumé}

Cette recherche artistique propose l'idéation du corps abject, compris dans un sens théorique et scénique. L'article est divisé en trois parties : une étude théorique, un laboratoire d'étape et une étape de production/démontage. Il est théoriquement soutenu par les oeuvres de Judith Butler : Bodies that Matter, on the Discursive Limits of Sex (2008), Julia Kristeva: Powers of Horror. An Essay on Abjection (1988) ; La méthodologie est basée sur le texte d'Ericka Fischer-Lichte : Aesthetics of the Performative (2017). Notre recherche aboutit à la création d'une dramaturgie corporelle basée sur ce qui a été créé dans le laboratoire de scène, et à un bref démontage du processus de création et de recherche scénique. Parmi les principaux résultats, il y a la compréhension et l'étude sur scène d'un concept, la possibilité de pratiquer l'art pour générer de nouvelles connaissances et les possibilités expressives du corps sur la scène dramatique.

\section{Mots clés}

Corps abject ; théâtre de danse ; laboratoire de scène ; production scénique ; performance ; théâtre physique

\section{Habitar o corpo abjeto: realização cênica a partir de um laboratório cênico}

\section{Resumo}

Esta investigação artística consiste na conceitualização do corpo abjeto, compreendido de forma teórica e cênica. Se divide em três partes: um estudo teórico, um laboratório cênico e uma montagem/desmontagem cênica. Se sustenta teoricamente, com o trabalho de Judith Butler: Corpos que importam, sobre os limites materiais e discursivos do sexo (2008), Julia Kristeva: Poderes do horror. Sobre a abjeção (1988); a metodologia se sustenta no texto de Ericka Fischer- Lichte: Estética do performativo (2017). A investigação culmina com a criação de uma dramaturgia corporal a partir do material criado no laboratório cênico e, uma breve desmontagem do processo de criação e investigação cênica. Entre as principais descobertas está a compreensão e estudo cênico de um conceito, a possibilidade da arte cênica de gerar conhecimento novo e as possibilidades expressivas do corpo em cena.

\section{Palavras chave}

Corpo abjeto; dança teatro; laboratório cênico; realização cênica; performance; teatro físico

\section{Kausai juru iuiakunaua: ruraikunata sugma churaspa nispa kawangapa}

\section{Maillallachiska}

Kai Achka tupuchispa kauachiku kausai jiru iuiakunaua iuakami kimsa parlai, iachachispa achaka, iachachispa. Mispa kauachingapa sugkunata, ministiku iapa imakuna, parlukuna imasa nukanchii kari warmi kaukaska kai watapi atun iskai waranga. Pusag kaura Ericka Fischer-Lichte: tupuchiku, imasami tari suma iuakuna iachaikungapa nispa sugkunata ialichingapa chasa mana wañuchu Nukanchipa kausai.

\section{Rimangapa Ministidukuna:}

Jiru iuiadur; mullurispa kauachii; ruraikunata wakachidiru; ruraikuna; suma Achka ruraikuna; ruraikunata kanchasinama apachii 


\section{Introducción}

La presente investigación, tiene por finalidad explorar escénicamente cómo ciertos cuerpos se encuentran al margen de lo normativo, cómo se expresan estos cuerpos y cuáles son las normas de las que se salen. Este salirse, se comprende como abyección. A través de una realización escénica sobre el cuerpo abyecto, nos aproximamos a una comprensión de las cualidades abyectas de los cuerpos, y las relaciones de poder, que inciden en que unos cuerpos sean más aceptados que otros. Entiéndase por cuerpo abyecto, a ese cuerpo o esos cuerpos, que son excluidos de lo social (deslegitimados) por ser diferentes a la norma, por tener otras expresividades, formas, $y$ performatividades.

Busqué explorar la capacidad de habitar el cuerpo abyecto y su abyección desde el recurso de las artes escénicas. El cuerpo abyecto, es ese que se sale de la norma, arrojado al exterior, que se queda al margen de lo socialmente aceptado; en un borde, donde se construye como diferente. Lo abyecto en esta investigación, y el cuerpo abyecto, se comprende como aquel que genera, dentro de lo social, repudio y exclusión por ser diferente a la norma:

Lo abyecto designa aquí precisamente aquellas zonas 'invivibles', 'inhabitables' de la vida social que, sin embargo, están densamente pobladas por quienes no gozan de la jerarquía de los sujetos, pero cuya condición de vivir bajo el signo de lo 'invivible' es necesaria para circunscribir la esfera de los sujetos. (Butler, 2008, pp.19-20)

La investigación artística se conforma de un estudio teórico, un laboratorio escénico y posteriormente la creación de una realización escénica, tomando como eje temático, el trabajo realizado por Judith Butler: Cuerpos que importan, sobre los límites materiales y discursivos del sexo (2008) y el de Julia Kristeva: Poderes del horror, sobre la abyección (1988); y como fundamento de la práctica el trabajo de Ericka Fischer-Lichte: Estética de lo performativo (2017).

Se dividió en tres etapas, una aproximación teórica al objeto de estudio, una segunda etapa práctica, de un laboratorio escénico, y una tercera etapa, en la cual se creó una realización escénica, donde se materializó y se entrelazaron las dos etapas anteriores. Finalmente, y como parte de la tercera etapa, se hizo un breve desmontaje escénico, basado en la definición de la autora lleana Diéguez (2010), que tiene la intención de visibilizar el recorrido y el entretejido que constituyó el quehacer escénico, desmenuzando el proceso mediante el cual se llegó al montaje presentado, sea este acabado o no.

Realicé el proceso de investigación escénica, con un grupo de 3 personas, profesionales de la danza y las artes escénicas, quienes formaron parte del laboratorio escénico y la realización escénica. Además, en cuanto al audiovisual y espacio escénico, tuve el apoyo de una escenógrafa y arquitecta.

Para la realización escénica, en esta investigación se entiende el teatro como proceso y no como una obra artística acabada. Es un medio para explorar e investigar el tema desde las artes escénicas. No se busca generar un producto acabado, más bien, crear un material escénico de estudio, en construcción constante, enfocada en el conocimiento y experiencia que se crea en el proceso de investigación propio de las artes escénicas.

\section{El cuerpo abyecto}

Durante la investigación, trabajé el concepto de cuerpo abyecto, a partir de una profundización de lo planteado por Judith Butler (2008) y Julia Kristeva (1988), generando una definición sustentada en la exploración teórica, que se puso en práctica y se amplió durante la etapa de creación y ejecución del laboratorio y posteriormente con la realización escénica.

La definición del concepto de cuerpo abyecto varía dependiendo del lente desde donde se vea. Diferencio, al menos dos formas, amplias, de comprender el concepto: el cuerpo abyecto en la vida cotidiana, y el cuerpo abyecto en el arte.

En el ámbito de la vida cotidiana, es, en primera instancia, ese que no puede reducirse a la forma diferenciada del sexo como norma regulatoria, es ese cuerpo inclasificable, que, además, se excluye de la norma de los cuerpos, y que no es entendido como "normal". "Abyecto, designa esas 


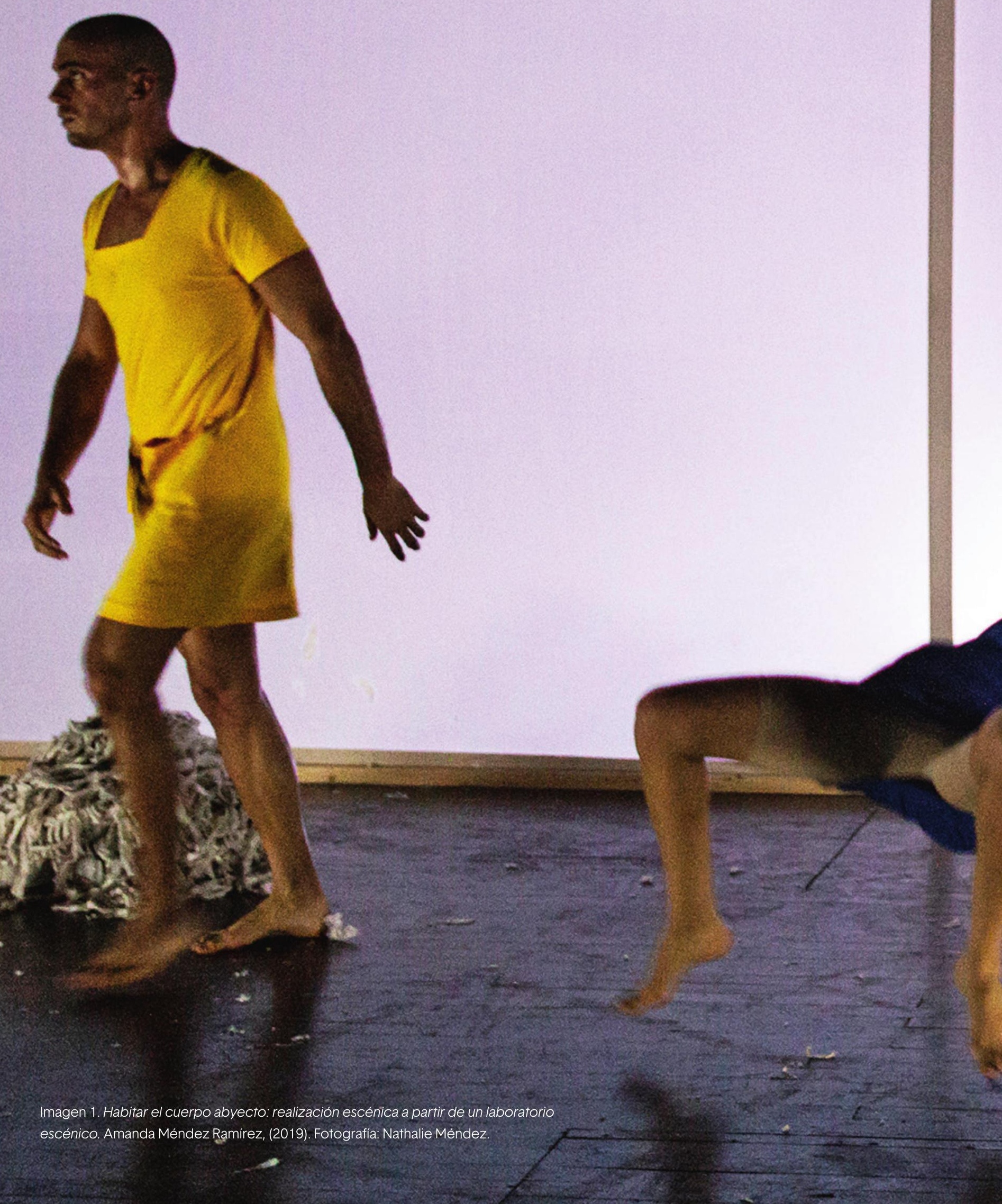




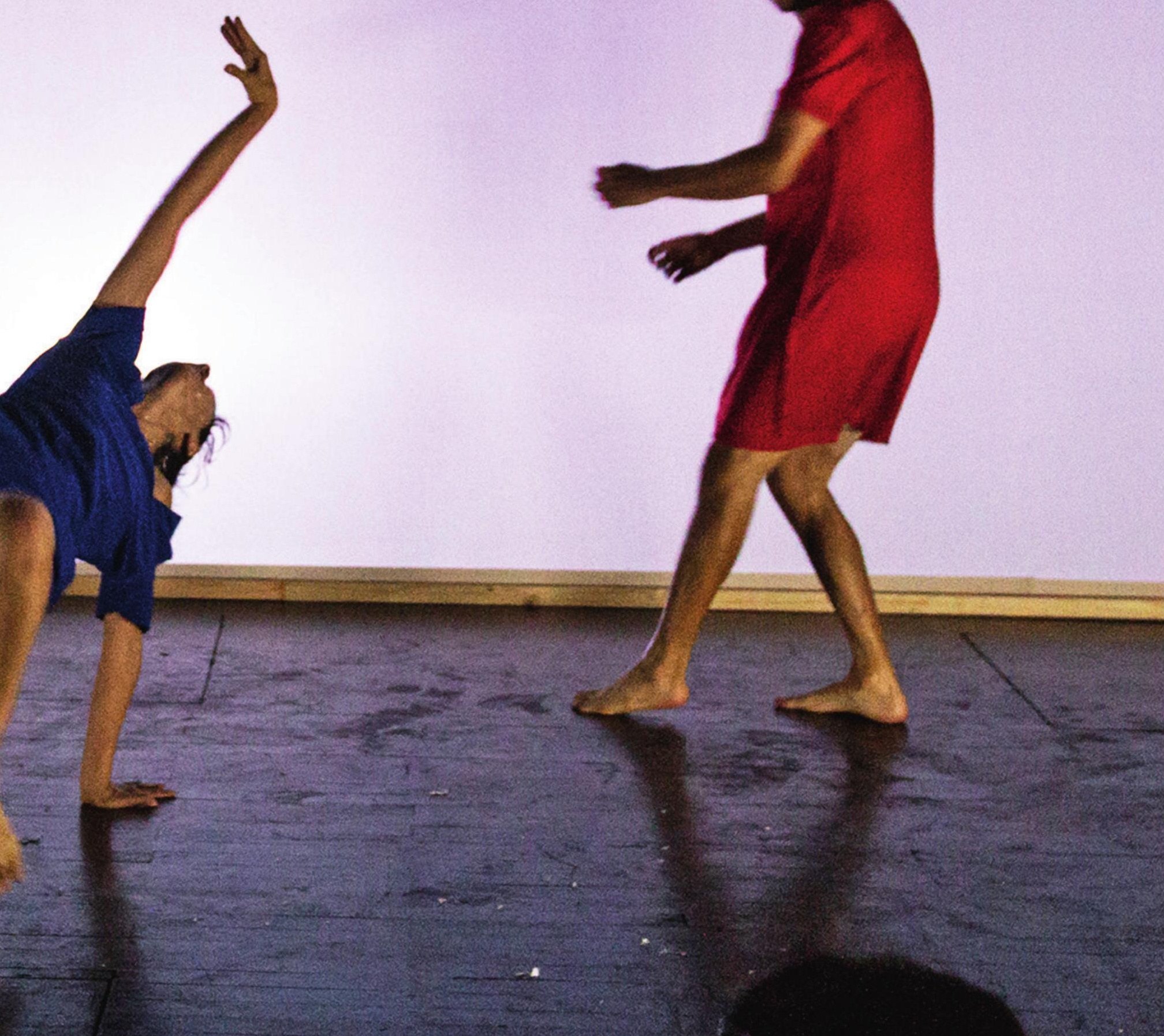


corporalidades que son inteligibles, que son inclusive categorizadas como no humanas, pues no calzan con los estándares sociales" (Butler, 2008, p.14). En cuanto al uso del cuerpo abyecto como campo discursivo, esto constituye, la definición normativa de lo que es humano y lo que no es. La normativa social cuestiona la humanidad misma de los cuerpos abyectos y utiliza medios para excluirlos.

Los cuerpos que se asocian con lo extraño, la fealdad, la vejez, lo perverso, inmoral, retorcido, queer, trans, entre otros, caben o, más bien, pueden caber en la categoría de abyectos. Sin embargo, para términos de dicho trabajo, no me detengo en categorizar los cuerpos, sino en ampliar, resignificar el concepto de cuerpo abyecto; contestar con el hecho, de que, estas cualidades se pueden resignificar, estos cuerpos se pueden habitar, entender. Paul Beatriz Preciado, en su Manifiesto Contrasexual, hace hincapié en dicho aspecto:
Así por ejemplo, bollo pasa de ser un insulto pronunciado por los sujetos heterosexuales para marcar a las lesbianas como "abyectas", para convertirse posteriormente en una autodenominación constestaria y productiva de un grupo de "cuerpos abyectos" que por primera vez toman la palabra y reclaman su propia identidad (Preciado, 2002, p. 24).

Me afianzo de la idea de que, como plantea Kristeva (1988), todos los cuerpos tienen algo de abyecto, algo que se abyecta y que es necesario para la misma constitución del cuerpo. Todas y todos tenemos, de una u otra manera, abyecciones. Retomando la idea de cuerpo abyecto en la vida cotidiana, este re-escribe lo que ya está constituido socialmente, irrumpe las leyes sociales que comprenden los cuerpos y el sexo como algo biológico y estable. Desde el punto de vista de Preciado (2002, p. 22), el sexo es más una tecnología de dominación heterosocial que una ley natural, y además, que reduce el cuerpo a zonas erógenas en función de una distribución asimétrica del poder entre los géneros.

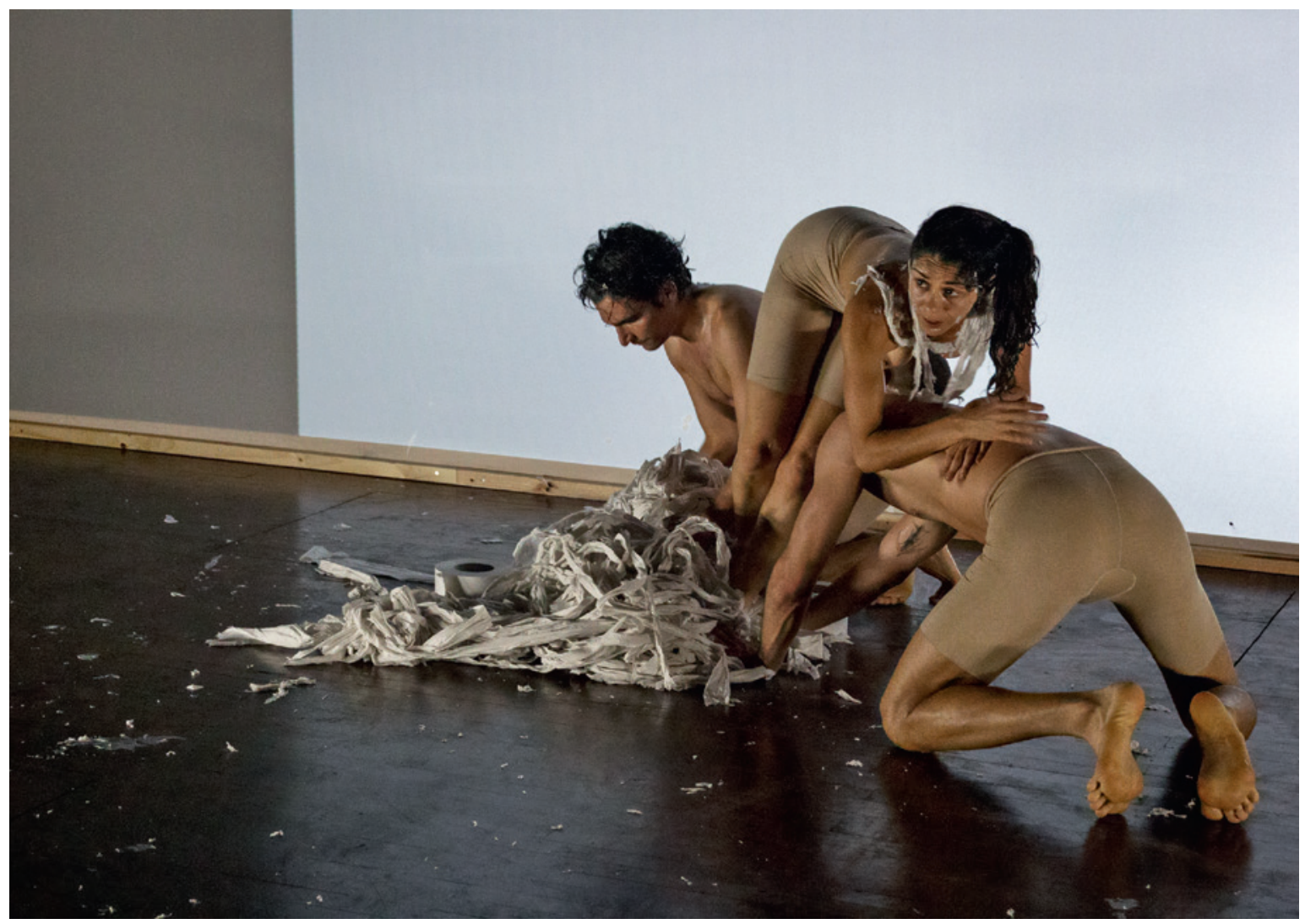




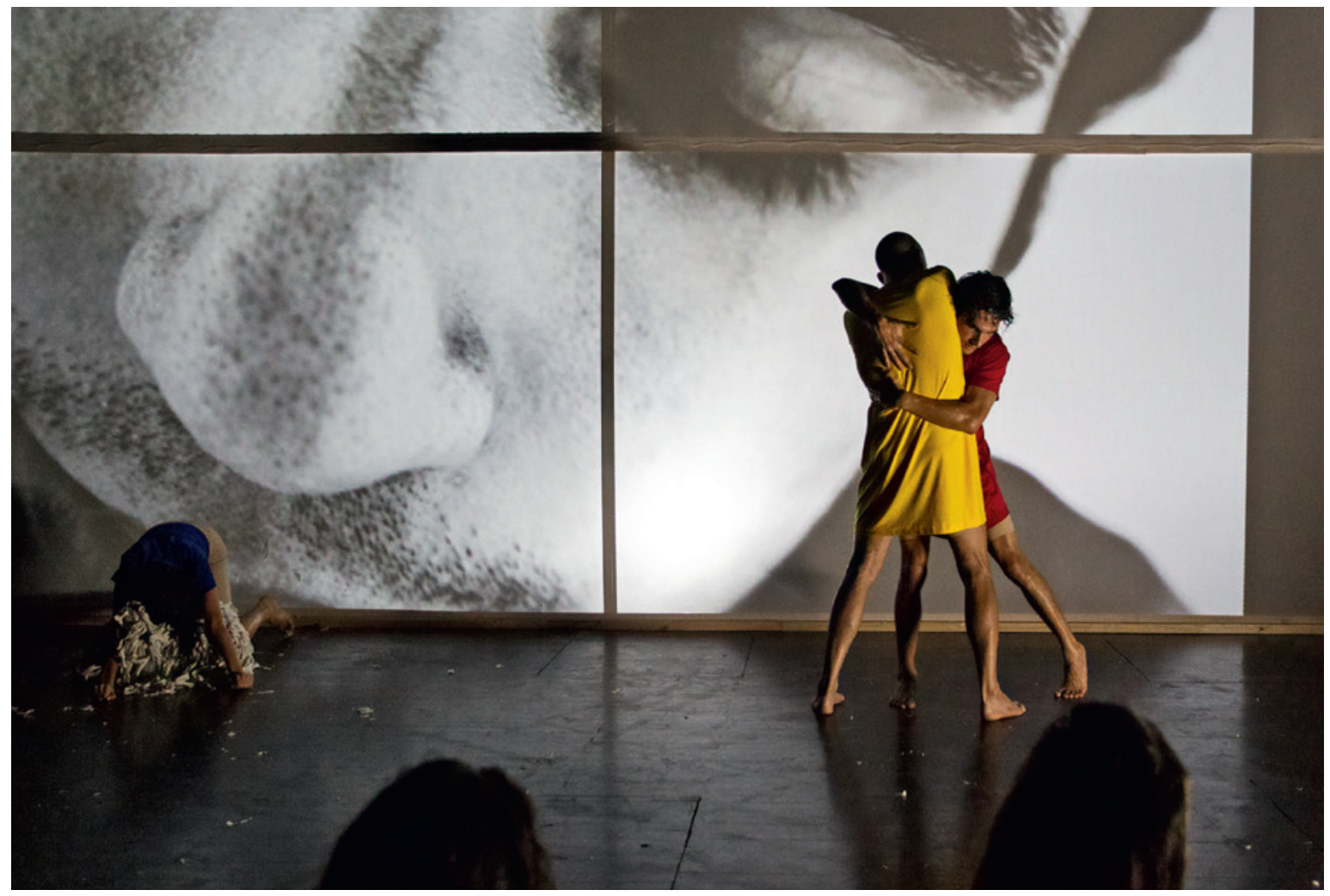

Imagen 3. Habitar el cuerpo abyecto: realización escénica a partir de un laboratorio escénico. Amanda Méndez Ramírez, (2019). Fotografía: Nathalie Méndez.

La idea de naturaleza humana como ley, reproduce en los cuerpos, los espacios y los discursos la idea de que "naturaleza" es igual a "heterosexualidad". Los roles y prácticas sexuales que se atribuyen naturalmente a los géneros masculino y femenino son un conjunto de regulaciones inscritas en los cuerpos que aseguran la explotación material de un sexo sobre el otro. Son construcciones sociales de dominación y poder.

Como lo plantea Preciado (2002), el cuerpo es un texto socialmente construido, un archivo orgánico de la historia de la humanidad como historia de la producción-reproducción sexual, en la que ciertos códigos se naturalizan, otros quedan fijados y otros son sistemáticamente tachados o rechazados, abyectos.

Judith Butler también expone que el sexo se materializa mediante su performatividad, pues se anuncia el discurso, se normaliza y se reitera en la norma regulatoria. Es decir, las leyes del sexo, se repiten a tal nivel, que son entendidas como lo normal, como lo que siempre es; $y$ todo lo que quede por fuera de eso, es abyecto, arrojado al vacío de lo social:

Lo abyecto designa aquí precisamente aquellas zonas "invivibles", "inhabitables" de la vida social que, sin embargo, están densamente pobladas por quienes no gozan de la jerarquía de los sujetos, pero cuya condición de vivir bajo el signo de lo "invivible" es necesaria para circunscribir la esfera de los sujetos. Esta zona de inhabitabilidad constituirá el límite que defina el terreno del sujeto; constituirá ese sitio de identificaciones temidas contra las cuales -y en virtud de las cuales- el terreno del sujeto circunscribirá su propia pretensión a la autonomía y a la vida. (Butler, 2008, pp.19-20)

Comprender el cuerpo abyecto como parte de lo social, habitable, da la posibilidad de reconstituir la legitimidad simbólica de los cuerpos, y la posibilidad de darle a estos la importancia que tienen. Una de las tesis básicas de Julia Kristeva, es la definición de lo abyecto desde una perspectiva política y cultural, pues defiende, que está vinculado con lo 
ilegítimo, en tanto que pone en cuestionamiento las normativas sociales y las leyes que rigen la expresividad de los cuerpos:

No es por lo tanto la ausencia de limpieza o de salud lo que vuelve abyecto, sino aquello que perturba una identidad, un sistema, un orden. Aquello que no respeta los límites, los lugares, las reglas. La complicidad, lo ambiguo, lo mixto. [...] Todo crimen, porque señala la fragilidad de la ley, es abyecto, pero el crimen premeditado, la muerte solapada, la venganza hipócrita lo son aún más porque aumentan esta exhibición de la fragilidad legal. (Kristeva, 1988, p. 4)

Esto amplía la concepción de lo abyecto a un marco de irrupción de la legalidad, de la normatividad; que abarca no solo la expresividad de los cuerpos, sino las acciones que estos realizan. También aporta un punto esencial desde el psicoanálisis, pues se entiende lo abyecto como todo eso que fue parte del cuerpo (lo pre-cultural) y que el sujeto busca diferenciar de sí mismo, cuando se constituye y se entiende dentro de lo cultural.

Desde esta perspectiva psicoanalítica, lo abyecto se constituye a partir de tres fases del sujeto: la oral, la anal y la genital; y se rige a partir de los bordes del cuerpo y lo que se relaciona con el mundo exterior: "[...] esas aberturas del cuerpo humano funcionan como borde entre lo que pertenece al cuerpo y lo que, por incumbir al mundo exterior, debe ser considerado como un objeto" (Ciénega, 2012, párr.10). Está relacionado con los procesos de construcción de identidad y socialización del cuerpo, y cómo las normas y reglas sociales construyen mediante relaciones de poder, los cuerpos abyectos y los cuerpos normales.

El estado, las leyes, las normativas y control sobre el cuerpo son patriarcales, todo lo relacionado con lo abyecto y el cuerpo abyecto es una construcción que se opone, que resiste a este orden patriarcal, es decir, el concepto se identifica con el feminismo crítico, con la crítica a la subordinación de los cuerpos, al orden heteronormativo y la moral impuesta desde el orden patriarcal:

Desde las normas morales y culturales, lo abyecto es todo lo otro, lo que se rechaza y se excluye: “...el Otro, "sujeto" y "objeto" se rechazan, se enfrentan, se desploman y vuelven a empezar, inseparables, contaminados, condenados, en el límite de lo asimilable, de lo pensable: abyectos". (Kristeva, 1988, p. 17)
En cuanto a la comprensión de cuerpo abyecto en el arte, el concepto toma un valor estético importante, pues se presentan todas estas cualidades prohibidas, inteligibles, rescatando su valor estético. En el arte, los cuerpos abyectos presentan lo que es inmoral, ilegal y prohibido en la cotidianidad; es decir, el arte legitima los cuerpos abyectos, permite presentar corporalidades que se buscan negar, invisibilizar. Al llevar al campo artístico esos cuerpos y corporalidades que en la sociedad son excluidos, estos se permiten habitar, presentar, estar dentro de la vida.

En el arte contemporáneo, lo que tiene que ver con el cuerpo abyecto, lo abyecto y las abyecciones genera una sensibilidad estética hacia eso que perturba, en tanto lo resignifican. Se escenifican esos elementos de la sociedad y del cuerpo que perturban la mirada de las personas espectadoras y se le da un lugar habitable a lo extraño, a lo que no se reconoce como propio del cuerpo. En el arte, lo abyecto adquiere valor, no como obra, sino como acontecimiento que perturba un orden. Desde el arte escénico, propiamente, se busca experimentar sobre la posibilidad expresiva de los cuerpos en escena, para visibilizar las restricciones y límites que se imponen sobre estos, abriendo la posibilidad de irrumpir la legitimidad y la normativa social:

[...] el cuerpo, en su particular materialidad, es el resultado de una repetición de determinados gestos y movimientos. Únicamente este tipo de actos dan lugar al cuerpo como algo individual, sexuado étnico y culturalmente marcado. Así pues, la identidad-como realidad corporal y social-se constituye siempre a través de actos performativos. 'Performativo' significa en este sentido, sin duda, como en Austin: constitutivo de realidad y autorreferencial. (Fischer-Lichte, 2017, p. 55)

La abyección, vista desde el punto de vista de las artes, es una categoría estética que busca recuperar lo real (experiencial) del cuerpo, es decir, no negar su realidad, sus secreciones, excreciones $y$ todo lo que puede entenderse como excluido culturalmente.

Lo Real es lo imposible, aquello que escapa a la significación, lo que está fuera del orden simbólico. Si lo simbólico era el reino del lenguaje, lo Real será lo que escapa a la significación, lo que está más allá de la ley, antes de que el sujeto se cree como tal. Lo Real será la prehistoria del sujeto y también aquello a lo que éste se incline, es el punto ciego del lenguaje. (Ciénega, 2012) 


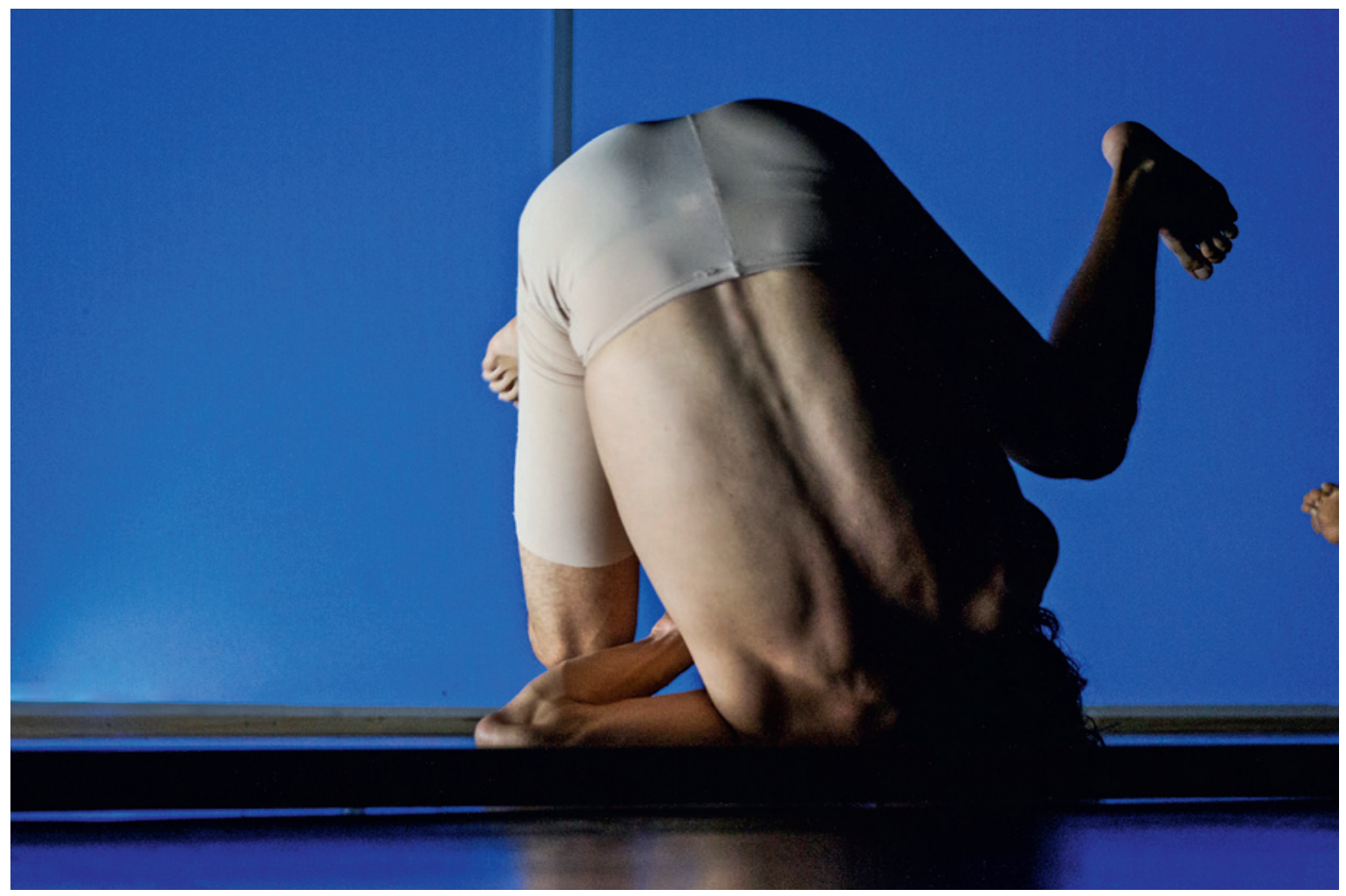

Imagen 4. Habitar el cuerpo abyecto: realización escénica a partir de un laboratorio escénico. Amanda Méndez Ramírez, (2019). Fotografía: Nathalie Méndez.

Es decir, lo abyecto en el arte problematiza no solo al(a) actuante/performer, sino que también pone en cuestionamiento al(a) espectador(a), ya que le presenta situaciones o expresiones artísticas sobre lo ilegal, lo excluido o prohibido:

Esta concepción artística de lo abyecto no representa imágenes exactamente bellas, pero éstas ejercen la fascinación de situar al espectador ante lo prohibido y lo siniestro, en términos freudianos: "Io unheimlich". Imágenes que son verdaderamente fascinantes porque causan todo, menos indiferencia. (Ciénega, 2012, párr.7)

Entonces, el cuerpo abyecto en el arte escénico, se caracteriza por ser ambivalente, pues busca desde lo cultural-simbólico, calar en la realidad, y penetra en el espectador(a) desde los sentidos, pero primordialmente desde la mirada, y desde ese lugar, les presenta lo prohibido, y lo que el orden social y el orden artístico no se permiten mostrar. Y sin embargo, genera interés y llama a ser visto. Busca perturbar el orden, es subversivo, al presentar aquello que no se quiere ver, pero que sin embargo está ahí y no se puede negar. En las artes escénicas, lo abyecto se expresa mediante lo sublime, toma del arte la estética, la forma para presentar lo real, para llevarlo al campo de lo simbólico, y traslaparse entre lo artístico y lo real (lo abyecto). Lo sublime y lo abyecto se entremezclan en el arte, pues son dos formas de un mismo proceso que suspende al sujeto, que lo desborda, al mismo tiempo que extralimita el orden simbólico.

\section{La realización escénica}

Una realización escénica es una creación artística conformada por actos performativos, movimientos y acciones corporales que se construyen en escena; se construye conforme se realiza, pues su cualidad esencial es la autopoiesis, es decir, se construye a sí misma mientras se ejecuta. Está enfocada en ver el montaje escénico como un proceso, no como una obra artística, rescatando, además, la interacción y co-presencia de intérpretes y espectadores(as). 


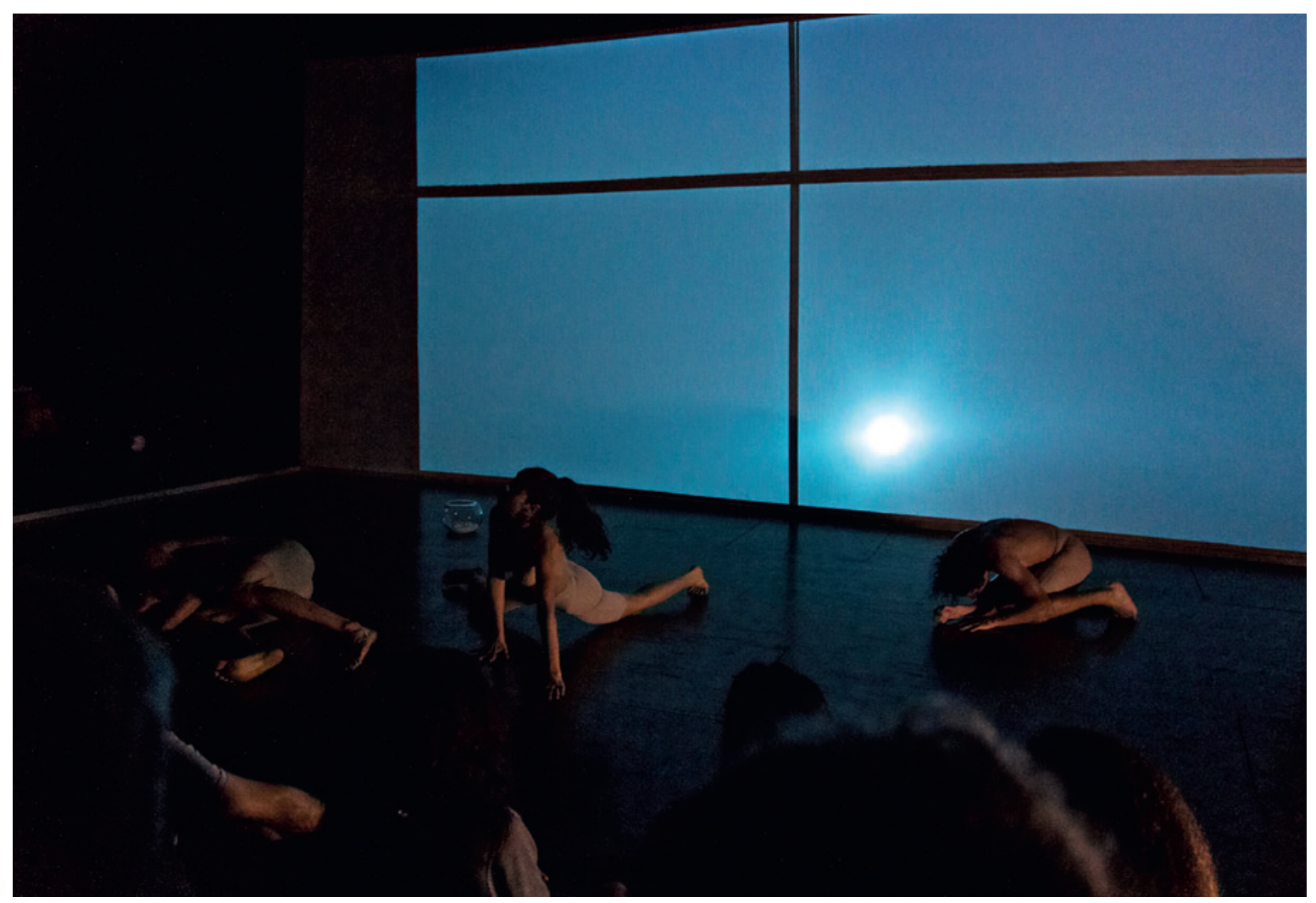

Imagen 5. Habitar el cuerpo abyecto: realización escénica a partir de un laboratorio escénico. Amanda Méndez Ramírez, (2019). Fotografía: Nathalie Méndez.

Se compone y se construye mediante actos performativos, que son el medio de expresión de lo vivo y lo efímero que compone la realización escénica. Se caracterizan por la supremacía del cuerpo como medio expresivo, distanciándose del teatro convencional, en el cual los actores o actrices reproducen y representan un papel, un personaje o un texto.

La realización escénica, comparte con el teatro danza, la posibilidad de no tener una narrativa convencional que seguir, está compuesta de episodios, acontecimientos y acciones que no necesariamente están tejidas entre sí, que no siguen una lógica convencional; sino que transita por estados, emociones $y$ acciones que adquieren significado en el momento en que se ejecutan, que giran en torno a un tema, pero no necesariamente tiene una lógica o narrativa lineal.

Las realizaciones escénicas no son un artefacto material fijable ni transmisible, son fugaces, transitorias y se agotan en su propia actualidad, es decir, en su continuo devenir y desvanecerse, en la autopoiesis del bucle de retroalimentación. Esto no excluye en ningún caso que en ellas algunos objetos materiales - decorado, atrezo, vestuario- tengan su función, que haya objetos que al final de la realización escénica se mantengan como tales [...]. La realización escénica, no obstante, se pierde irremediablemente al terminar y no se puede repetir nunca de forma idéntica. (Fischer-Lichte, 2017, p. 155)

La narrativa o dramaturgia de la realización escénica se crea en torno a la temática que aborde, su estructura no es rígida, se va construyendo conforme se crea, mediante las acciones escénicas. No son puestas en escena, acabadas o conclusas, están en creación constante; permitiéndose ser un material escénico de estudio y análisis.

\section{Desde la realización escénica se comprende el} arte escénico como acontecimiento y no como obra. "La realización escénica es la esencia de lo performativo" (Fischer-Lichte, 2017, p. 59). Utilizar este concepto, es comprender el arte escénico 
como acontecimiento, como realización escénica y no como texto u obra teatral. Entendiendo que existe una co-presencia física: una convivencia e interacción entre intérpretes y espectadores(as).

La realización escénica exalta esa cualidad artística del arte escénico, es decir, la co-presencia de los/las intérpretes y el público (su mirada, gestos, percepción). Todos los demás elementos, están al servicio de esta relación viva y real que se crea en el aquí y el ahora. “[...] para la experiencia estética lo más decisivo teatralmente en la realización escénica es la experiencia conjunta de los cuerpos reales en un espacio real" (Fischer-Lichte, 2017, p. 73).

Ella pasa en un presente, existe en un espacio-tiempo específico, se crea conforme se está realizando y se construye a sí misma en escena, en la realidad presente. Pertenece al ámbito de la experiencia, de lo que se esfuma conforme está aconteciendo, es la cualidad efímera de lo escénico, es lo que se deshace conforme se crea; y se caracteriza por estar viva:

Las realizaciones escénicas -artísticas- más difíciles, son las que apuntan a un lugar que siempre se va a escapar porque siempre va a estar más allá o más acá de la mirada, incorporándose en los cuerpos -valga la redundancia-, son las que se construyen desde los límites hechos visibles de estos cuerpos como máquinas de interpretar, y desde ahí permiten pensar - quiero decir: sentir- de la historia de las representaciones o de la historia de las teorías, que es otra forma de representación (Fischer-Litche, 2017, p. 19).

Jorge Dubatti, crítico e historiador teatral argentino, en sus aportes a la Filosofía del Teatro: “Una filosofía del teatro se diferencia de la filosofía a secas por su interés particular en el ser peculiar del acontecimiento teatral, un ser de estar, acontecer en el mundo" (2010, p. 2). Dubatti se refiere al teatro como acontecimiento: donde rescata esa cualidad viva y efímera del arte escénico, en donde su teoría se encuentra con la concepción de realización escénica.

La Filosofía del Teatro afirma que el teatro es un acontecimiento (en el doble sentido que Deleuze atribuye a la idea de acontecimiento: algo que acontece, algo en lo que se coloca la construcción de sentido), un acontecimiento que produce antes en su acontecer, ligado a la cultura viviente, a la presencia aurática de los cuerpos, y a partir de esa proposición, elabora argumentos fundamentales que cuestionan el reduccionismo a la definición semiótica del teatro. (Dubatti, 2010, pp. 11-12)
Según esta postura, la realización escénica se caracteriza por generar, en primer lugar, relación entre el público/espectador y el/la intérprete, en segundo lugar, se da la autopoiesis, la cualidad de crearse en el momento presente y esfumarse, ser efímera.

Mario Cantú (2012), también se refiere a esta cualidad última, esencial del "teatro", el cual puede prescindir de escenografía, luces, vestuario, espacio diferenciado (escenario), y que, depende de una única relación: intérprete-espectador(a). Esta cualidad, es a la que responde el concepto de realización escénica, que busca rescatar la cualidad principal del arte escénico, la relación presente, en el aquí y el ahora, de las/los espectadores e intérpretes. Jerzy Grotowski, también se refiere a esto, con un concepto al que denomina teatro pobre, es decir, un teatro, que más allá de ser pobre, se ha constituido a sí mismo desde lo negativo, lo que quiere decir, que ha renunciado a todos los elementos de los cuales puede desprenderse, para comprenderse a sí mismo ontológicamente.

De ahí el teatro pobre. Pobre porque ha ido renunciando a todas sus partes hasta dar con el constituyente esencial: la relación actor-público. Puede haber teatro sin escenografía, sin el edificio teatral, sin maquillaje ni luces, inclusive sin un texto previo (el texto puede hacerse durante la marcha en improvisaciones); lo único que se necesita para que haya teatro es un actor y un espectador. (Cantú, 2012, p. 17)

Entonces, la realización escénica está configurada como un proceso constante, inacabado, que se enfoca en el proceso más que el resultado. Busca tener otra relación, no tradicional, con los espectadores, donde el cuerpo del intérprete, no busca crear un personaje o representar una situación, más bien se comunica con el público tal como es, a través de herramientas de la performance, la danza butoh y la danza teatro, que, en ese sentido dialogan con la realización escénica.

\section{Metodología}

Esta investigación artística es de carácter teórico-práctica, se recolectó información basada en datos, estudios teóricos y observación de comportamientos, discursos, acciones; que posteriormente se interpretaron y se conectaron con el trabajo práctico/escénico, la sistematización del proceso y el abordaje experiencial y creativo. 


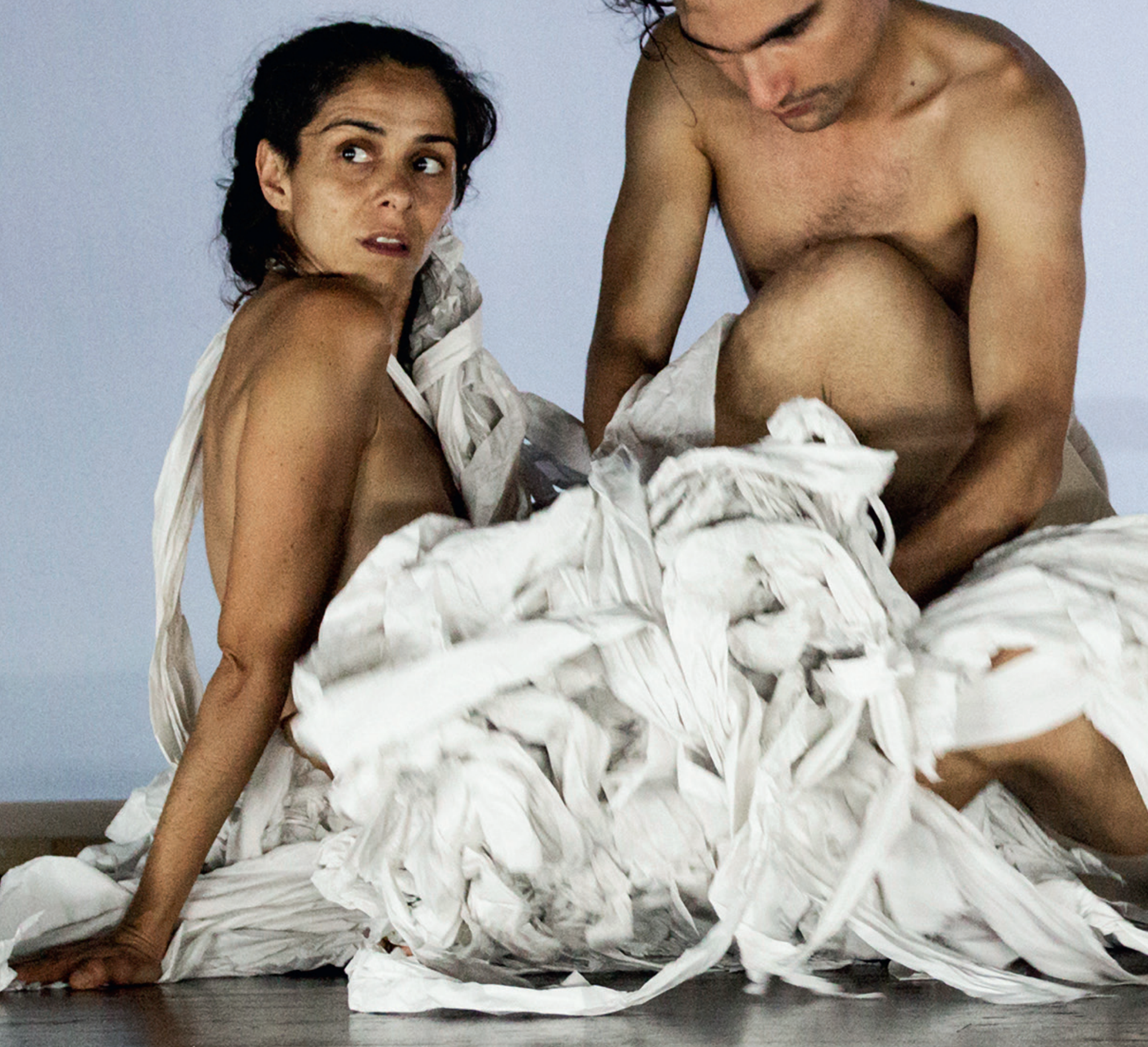




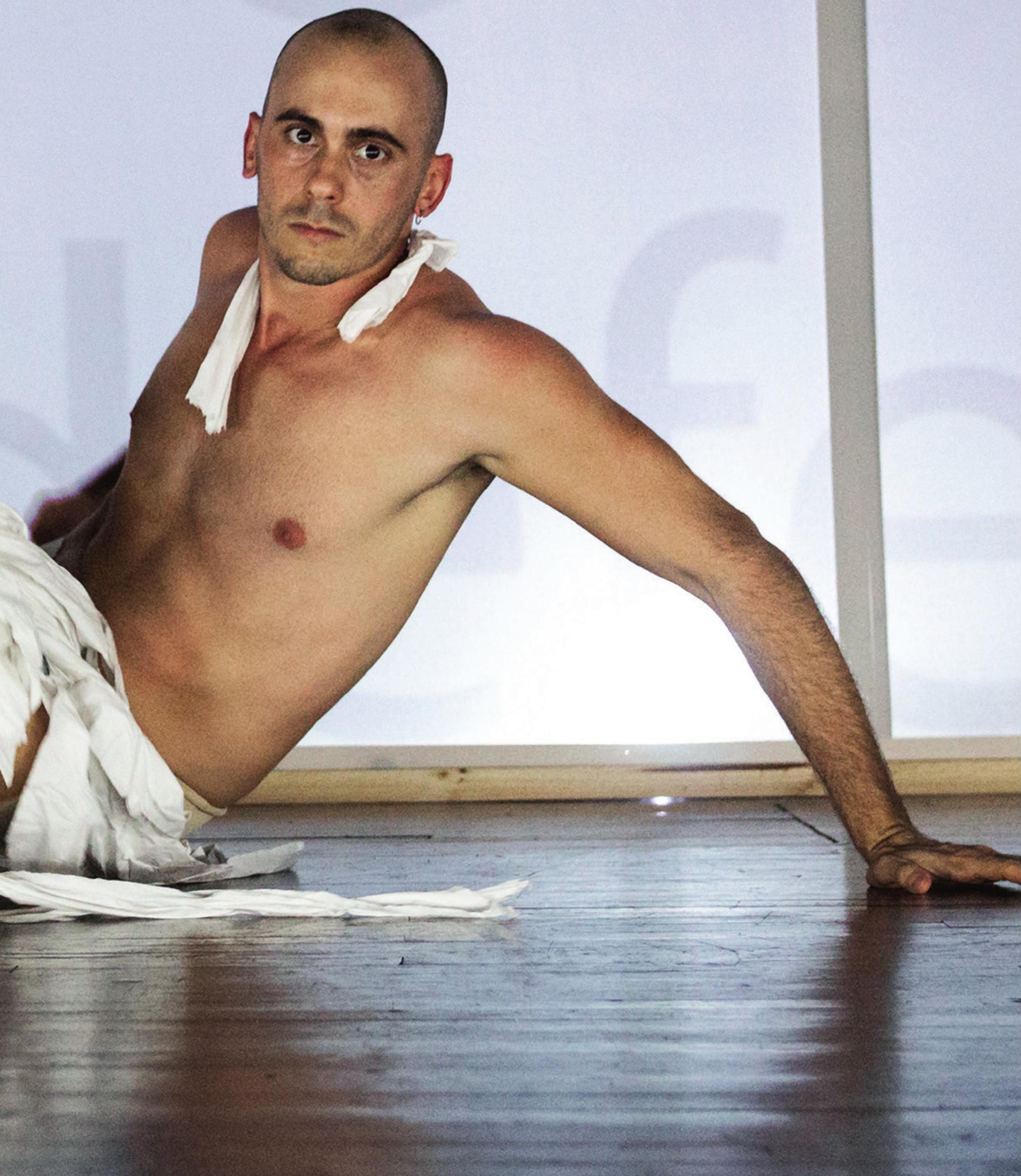


Se dividió en tres etapas, que respondieron a los objetivos planteados: una primera, enfocada en la conceptualización y estudio del eje temático, basado prioritariamente en bibliografía y estudios, vinculados al tema del cuerpo abyecto y la realización escénica; además, se realizó un pre-laboratorio (experiencia personal) y luego se construyó el programa del laboratorio escénico.

Una segunda etapa, se enfocó en llevar lo estudiado sobre el cuerpo abyecto a la experimentación, mediante un laboratorio escénico; explorando el tema, mediante ejercicios escénicos, performativos y mediante juegos teatrales enfocados en el trabajo corporal, que propiciaron la expresión escénica del tema.

Por último, en una tercera etapa, se creó la realización escénica, que se basó en las experiencias registradas en el proceso, mediante la bitácora de la práctica artística, que utilizaron las(os) intérpretes, como creadores-investigadores y yo, como creadora e investigadora escénica. Luego se hizo la selección del material creativo y escénico, que propició la dramaturgia corporal de la realización escénica, abordando los diversos temas estudiados y explorados, en torno al cuerpo abyecto. Finalmente se hizo un desmontaje escénico, donde se amplía sobre el proceso de creación e investigación que constituyó la realización escénica.

Para esta investigación, utilicé recursos metodológicos que se aplicaron en la práctica para llevar a cabo, tanto el laboratorio escénico (etapa 2) como la realización escénica (etapa 3). Utilicé elementos y recursos metodológicos del teatro físico, la danza teatro, la danza butoh. Rescaté elementos y ejercicios específicos que proponen estos campos del arte escénico, en tanto fueran pertinentes para esta investigación. Cada uno de estos recursos se planteó por su pertinencia práctica para la investigación.

Utilicé como material de registro y sistematización la bitácora de la práctica artística, basándome en una de las propuestas metodológicas de Rafael Pérez Arroyo, en su texto: La práctica artística como investigación: el diario de la práctica artística que destaca como una de las herramientas más importantes para el proceso de investigación en las artes:
Permite reflejar día a día los avances y las crisis que se producen tanto en la dirección propuesta inicialmente como en los cambios de itinerario que consignan materializarse. Al mismo tiempo, refleja la influencia de los elementos externos que puedan intervenir en la toma de decisiones durante el proceso, como determinadas lecturas, películas, artículos, etc. (Pérez, 2012, p. 63)

Durante la investigación hice uso constante (en cada sesión) de la bitácora de práctica artística, que acompañó las tres etapas de investigación, además, del registro fotográfico y de video. También las(os) intérpretes utilizaron su bitácora personal para registrar aprendizajes, cuestionamientos, experiencias, sensaciones que se fueron creando durante el proceso del laboratorio escénico y la realización escénica.

Es pertinente aclarar, que las etapas en las que se dividió este trabajo no tuvieron un carácter cerrado, es decir, se entrelazaron entre sí y existió una constante revisión de los eventos previos para la creación de las actividades y ejercicios planteados.

\section{Resultados}

La investigación y su proceso de sistematización, funcionó en sí, como un desmontaje escénico, en tanto se describió paso a paso, cómo se fue construyendo la investigación y me enfoqué en dibujar cual ha sido el proceso detrás de la realización escénica. La bitácora artística, las fotografías, los videos, la escenografía, los objetos escénicos, el vestuario, el proceso de investigación-creación de la intérprete y los intérpretes, los errores, las búsquedas, las discusiones en torno a los temas, entre otros, todo esto forma parte del desmontaje escénico.

Ahora bien, inicio rescatando el aporte de la y los intérpretes: Diana Betancourt Villa, Dayron De León Castillo y Alonso Brenes Vargas; pues fue esencial para el desarrollo del proyecto. Su actitud fue bastante propositiva y expresaron interés durante todo el proceso. También el trabajo de M.A Alejandra Méndez Ramírez, como artista audiovisual y escenógrafa fue de gran soporte al proceso; desde la fotografía y el video de los ensayos, hasta 


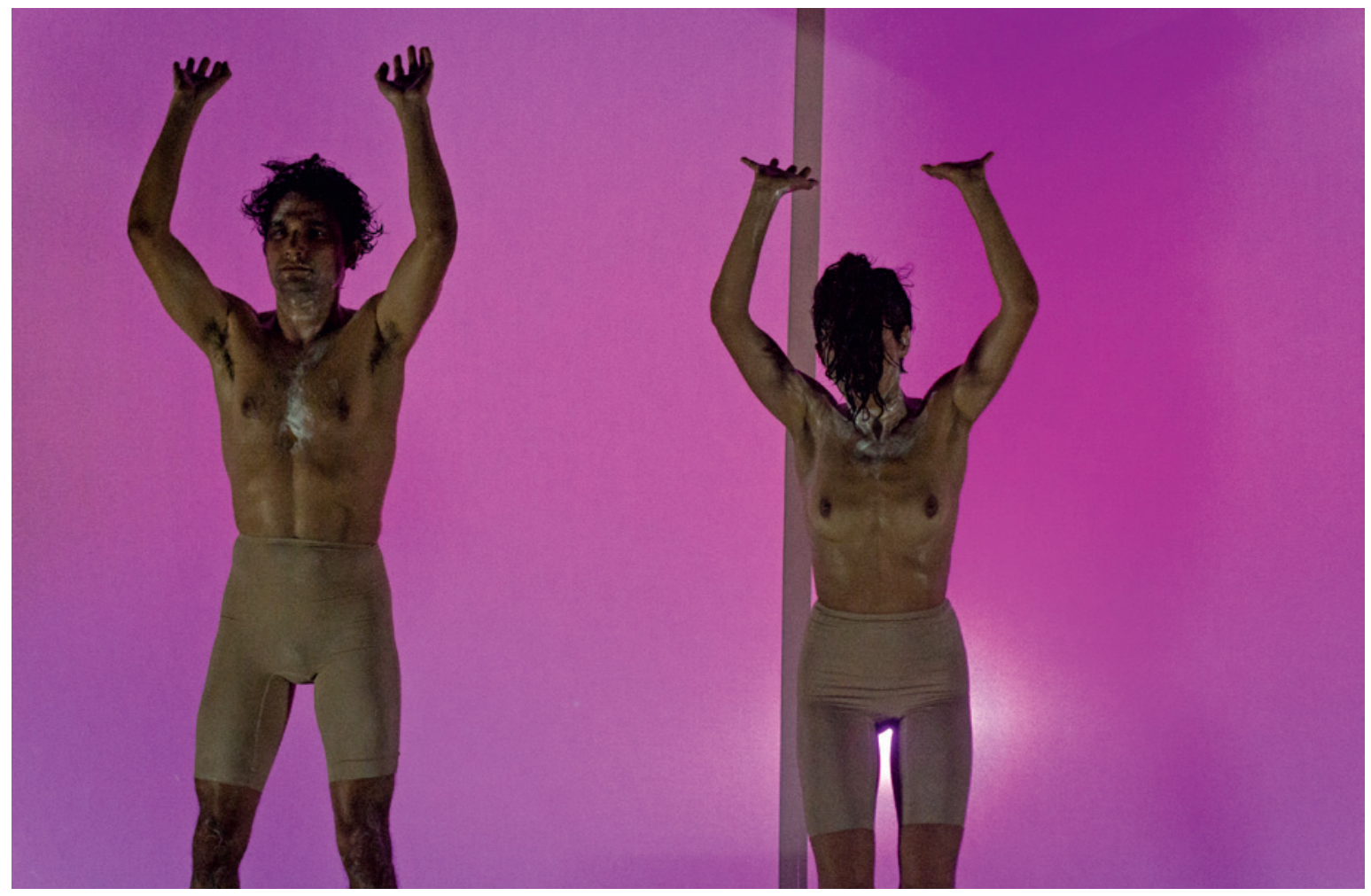

Imágenes 7 y 8. Habitar el cuerpo abyecto: realización escénica a partir de un laboratorio escénico. Amanda Méndez Ramírez, (2019). Fotografía: Nathalie Méndez.

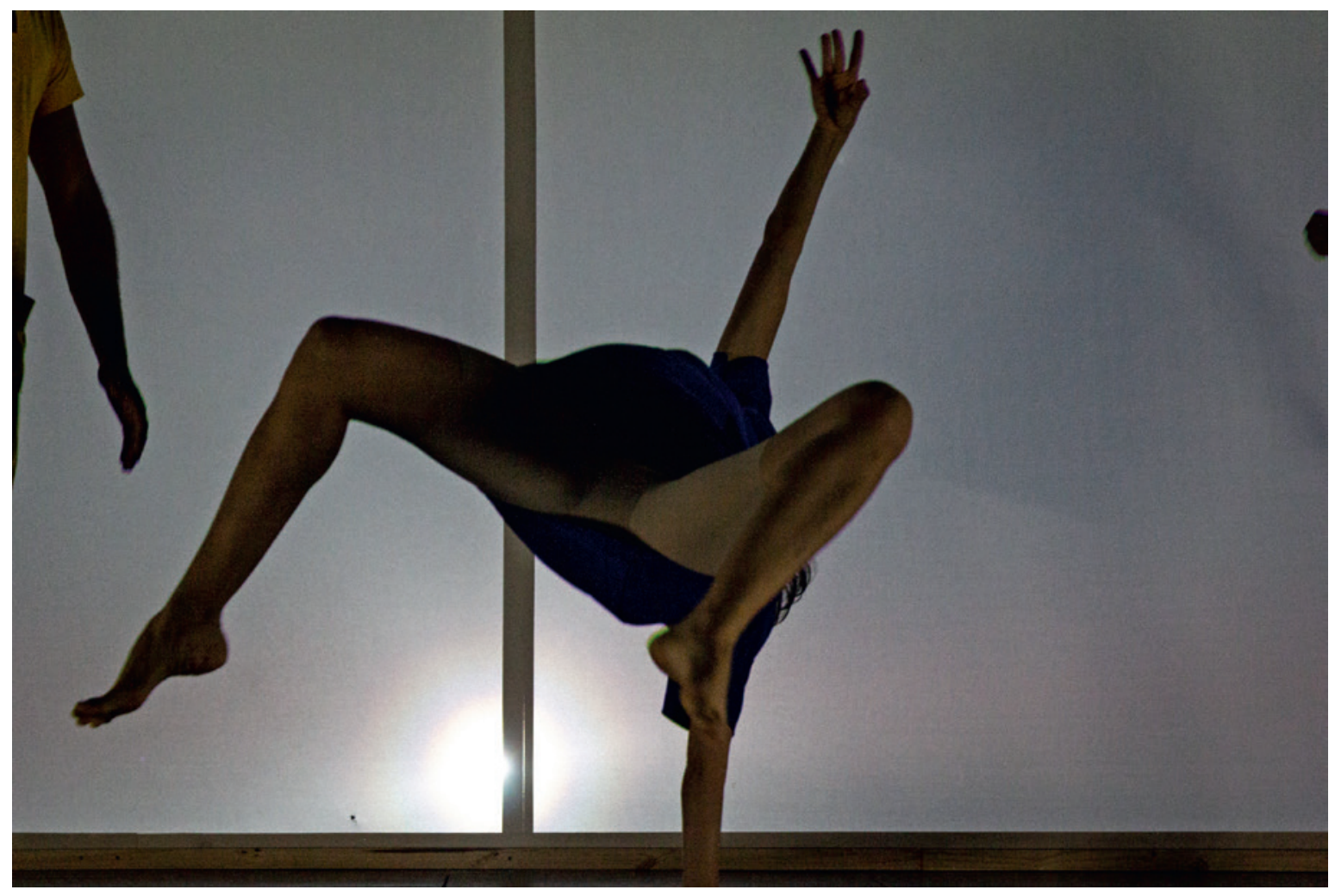


la creación de los videos para la realización escénica propiamente.

La presencia de las(os) artistas que me acompañaron y nuestro convivio, fueron esenciales durante el desarrollo de la investigación. La constante retroalimentación, el apoyo mutuo fueron alimentando la investigación. Los tres, asumieron el papel de intérpretes creadores, quienes, al tener conocimiento en prácticas y disciplinas distintas, contribuyeron al proceso de creación e investigación. Como intérpretes, no buscaron crear resultados, sino que compartieron sus procesos de búsqueda, investigación y construcción escénica, generando un proceso en el que la presencia escénica fue esencial. Alejandra Méndez Ramírez, licenciada en arquitectura y master en escenografía, (Norwegian Teather Academy), aportó desde la construcción de la escenografía, la proyección audiovisual y la sistematización con fotografía y video de gran parte del proceso (especialmente el laboratorio escénico), además me apoyó con el proceso de producción de la realización escénica.

Al ser un proceso en construcción, y haberse visto afectado por temas de tiempo y espacio para ensayar, en el tiempo que logramos trabajar, quedaron algunas cosas por ajustar y precisar, sin embargo, esto también era algo que habíamos contemplado, es una cualidad de la realización escénica, ser un proceso inacabado, en construcción constante y con la finalidad de ser un material de estudio. Que a su vez tiene la riqueza de poder crecer escénicamente y ser presentado en futuros espacios.

La cualidad de la realización escénica, permite que cada muestra, cada ensayo sea diferente. El elemento de la improvisación de la danza teatro también estuvo presente durante la realización escénica. A pesar de que había una marcación o dramaturgia corporal que guio o estructuró la realización escénica, la libertad de sentir y crear durante la escena fue algo esencial en el proceso. Si bien gran parte de la realización escénica se estructuró para su mayor comprensión (tanto desde dentro como desde afuera), la gran mayoría de acciones y movimientos pasaron por la improvisación, por el sentir el cuerpo y crear en el aquí y el ahora.
Mi familia estuvo implicada en el proceso de creación e investigación escénica, fueron parte del equipo de trabajo y apoyo logístico y de producción. En fin, durante el año que estuvimos trabajando, se generó una red de interacciones que se fueron afectando, cambiando, alimentando durante todo el proceso. Surgieron reflexiones sobre la práctica que permitieron que el proceso de investigación y creación fuera un híbrido, que se contaminó por distintas perspectivas, áreas de conocimiento: filosofía, sociología, arquitectura, danza, escenografía, artes visuales, entre otras.

La muestra de la realización escénica, es solo la "punta del iceberg", ya que detrás de lo que se ve, al igual que en muchos, por no decir todos los procesos de creación escénica, (u otras áreas), hay toda una red de trabajo, esfuerzos, experiencias, pruebas y errores, conflictos, momentos de crisis, procesos. Y eso es lo que hace que el proceso de investigación artística sea tan valioso, que haya sido tan "rico" y amplio. En realidad, fue un proyecto complejo, que implicó mucho trabajo procesual, mucha sistematización y conciencia, para no dejar de lado el aprendizaje en las primeras etapas y permitir que el proceso se fuese alimentando.

\section{Conclusiones}

Una de las principales conclusiones de este trabajo, es que nos podemos aproximar a la definición de un concepto a través de la práctica, la práctica escénica, propiamente. Llevándolo al cuerpo y a la escena, pudimos sacar provecho del estudio teórico, tener momentos de reflexión en torno a cómo se construyen las corporalidades y cómo la construcción social de cuerpo abyecto, está determinada por aspectos históricos, culturales, morales, estéticos que se imponen sobre los cuerpos y que generan otredades y alteridades que son violentadas, y a su vez, necesarias para mantener un orden y un poder opresor.

El proceso de análisis del concepto de cuerpo abyecto se construyó como una espiral, en tanto, inicié estudiándolo teóricamente, luego comprendiéndolo y definiéndolo desde la práctica y el cuerpo mismo, posteriormente, regresé(regresamos) a una definición, pero esta vez distinta, ya 
atravesada por la experiencia, la experimentación y las vivencias cotidianas y escénicas de él mismo.

El papel de creadora e investigadora escénica, que desarrollé durante todo el proceso, me abrió una mirada mucho más amplia de los alcances que pueden tener las investigaciones en las artes escénicas, la posibilidad que existe de identificar temáticas sociales, culturales y darles un sentido personal, propio, desde el arte escénico; generar conocimiento artístico sin desvincularse de la importancia de comprenderse como parte de una sociedad, de normas, estructuras que nos envuelven.

El proceso colaborativo, de creación conjunta, de escucha y empatía, es un elemento esencial para la creación e investigación desde las artes escénicas. Estoy convencida, de que colectivamente, es como se nutre y se construye una creación escénica, una realización escénica.

El feminismo o mejor dicho, los feminismos, teorías feministas, como la de Judith Butler, Beatriz Preciado, Julia Kristeva, pero también muchas otras; fueron parte esencial de este proceso, una columna vertebral, a nivel personal, político, artístico. El enfoque de género y el feminismo, sostuvieron el trabajo realizado; intenté mantener una relación horizontal con las personas intérpretes que me acompañaron, generando discusiones críticas en torno a la construcción de categorías, de roles. El papel de las mujeres, los hombres, las personas que son vulnerables, migrantes, población LGTBI+, entre otros seres que se ven afectados por estas construcciones binarias, violentas, por los ideales de cuerpos y comportamientos normados.

El material presente, es solo una pincelada del proceso de construcción de ideas, posturas, pensamientos, posiciones que atravesamos durante el proceso, porque siempre quedan cosas en el cuerpo, la memoria y experiencia, que no están acá. Los encuentros, las palabras, las discusiones sobre los temas, los aportes y conocimientos específicos de cada quien, los cafés, las películas, imágenes, movimientos que acompañaron el proceso, fueron elementos claves para la construcción de este proyecto.
Con este proceso, encontré, que lo abyecto, y el cuerpo abyecto, es un concepto con pluralidad de significados, que varía dependiendo del eje o intención con el que se estudie; es un concepto difuso, con gran cantidad de sentidos y posibilidades semánticas. Sin embargo, me es claro, que el concepto abarca construcciones históricas, psicosociales, culturales, estéticas, artísticas, que construyen dicotomías, alteridades, y que a su vez, determinan la construcción de los cuerpos, sus límites morales, legales, estéticos. Nos construimos desde esa búsqueda de negar la abyección en nuestro cuerpo, pero hay resistencias culturales, estéticas, políticas, que buscan desmitificar los ideales, las normas sociales y el orden patriarcal y represor.

He llegado a la conclusión, de que hay que habitar las abyecciones, desde sus múltiples posibilidades: el cuerpo, sus fluidos, las aperturas, las construcciones no binarias, diferentes a la norma, los comportamientos no aceptados, las acciones que irrumpen el orden moral y cultural. Replantear la categoría de prohibido, excluido, inmoral, asqueroso, enfermo, contaminado, abyecto de los cuerpos. Habitar el cuerpo abyecto es una invitación a re-significar los cuerpos, borrar dicotomías, violencias simbólicas y materiales, aceptar la muerte, la putrefacción, las sombras, los fluidos, los cuerpos, porque, al fin y al cabo, todos, sean como sean, son importantes.

La realización escénica fue un referente y medio artístico óptimo para escenificar la expresión de los cuerpos abyectos desde la identidad, lo social y lo cultural. Además, el lenguaje del cuerpo y sus actos performáticos contribuyeron a la cualidad viva de la realización escénica, permitiendo expresar lo abyecto desde las acciones escénicas reiterativas, mediante la repetición estilizada de actos y acciones corporales, que generan cuerpos marcados y construidos, en gran medida, social y culturalmente.

Esta realización escénica sobre el cuerpo abyecto, se desarrolló bajo la corporización y el campo de acción del(a) artista/performer, donde se comprendió su participación como algo experiencial. Aprovechando la fisicidad de los cuerpos, como territorio de acción desde lo sensible, desde el juego y la experimentación a través de la 
experiencia propia, personal, emotiva. El cuerpo tomó un lugar esencial en la comprensión de lo abyecto, pues no pudimos comprender mejor el concepto, que llevándolo al cuerpo mismo. Trabajamos con el hecho de que el cuerpo está en constante lucha consigo mismo y con lo social y cultural.

El abordar el concepto desde el arte escénico, permitió que nos apropiáramos de la posibilidad expresiva de los cuerpos en escena, y así, desde nuestra propia experiencia, mirada personal, auto regulaciones, censuras; así como visibilizar las prohibiciones y límites que se imponen sobre los cuerpos, abriendo un poco más la posibilidad de irrumpir la legitimidad y la normativa social.

El campo de la realización escénica dio pie, a lo que desde lo normal, se plantea como imposible de realizar: [...] "¿cómo tales restricciones producen, no sólo el terreno de los cuerpos inteligibles, sino también un dominio de cuerpos impensables, abyectos, invivibles?" (Butler, 2008, p. 14).

Durante la investigación generamos, colectivamente, una redefinición del concepto que fue motor escénico; $y$ desde la práctica escénica, creamos una forma diferente de entenderlo, describirlo y apreciarlo. Escenificamos elementos de la dimensión residual de la sociedad y del cuerpo mismo, mediante acciones escénicas corporales (danza teatro y performance). Generando, desde un punto de vista personal y vivencial, una sensibilidad hacia lo abyecto: habitar esos espacios, esas dimensiones corporales y corporalidades.

Esta investigación desde las artes escénicas, contribuye a la noción contemporánea de "cuerpo que se está de-construyendo". Esta búsqueda está en el aquí y el ahora: la búsqueda de nuestra identidad, y esta búsqueda no solo se genera desde la academia sino también desde el arte, en las calles, en las casas y desde la cotidianidad. La forma en que nos hemos construido históricamente, desde nuestros roles de género y diferencias corporales es violenta, porque estratifica unos cuerpos sobre otros y se ha convertido en norma. Espero aportar a la reflexión sobre la importancia de desnaturalizar la estratificación de unos cuerpos sobre otros, y cuestionarnos los roles sociales que ocupamos. La presente memoria de proyecto de graduación se configuró como un desmontaje del proceso de creación y sistematización de la realización escénica, en tanto se descomprimieron, detalladamente, las etapas que lo constituyeron durante todo el proceso de investigación.

\section{Referencias}

Butler, J. (2008). Cuerpos que importan. Sobre los límites materiales y discursivos del sexo, Buenos Aires: Paidós.

Cantú, T. M. (2012). Laboratorio teatral. La ideología científica en el discurso de Jerzy Grotowski, Revista Telón de Fondo, (15).

Ciénega V. E. P. (2012). Mutaciones del cuerpo, reflexiones en torno a lo abyecto en las prácticas estéticas contemporáneas, Metapolítica, 16(79), pp.23-29. Recuperado de: «http:// www.iztacala.unam.mx/errancia/v1/PDFS_1/POLIETICAS1_ MUTACIONESDELCUERPO.pdf»

Diéguez, I. (2009). Escenarios y teatralidades liminales. Prácticas artísticas y socioestéticas, Archivo virtual artes escénicas.

Diéguez, I. (2010). Desmontando escenas: estrategias performativas de investigación y creación, Telondefondo: revista de teoría y crítica teatral, 12.

Dubatti, J. (2010). Filosofía del Teatro: fundamentos y corolarios. Gestos, 25(50), p.53.

Fischer L. E. (2017). Estética de lo performativo, Madrid: Abada Editores.

Kristeva, J. (1988). Poderes de la Perversión, (Pouvoirs de I'horreur), Sobre lo abyecto, Madrid: Siglo XXI.

Pérez A. R. (2012). La práctica artística como investigación. Propuestas metodológicas, Madrid, España: Editorial Alpuerto, S.A.

Preciado, B. (2002). Manifiesto Contrasexual, Madrid: Opera Prima. 